\title{
DRILL: An innovative programme to develop health research leadership in KwaZulu-Natal, South Africa
}

\author{
F Suleman, ${ }^{1}$ BPharm, MPharm, PhD; D Wassenaar, ${ }^{2}$ BA Hons, MA (Clin Psych), PhD; \\ N Nadesanreddy, ${ }^{3}$ MB ChB, FCPHM, MMed (Public Health Medicine); P Brysiewicz, ${ }^{4}$ BSocSc, BA, MCur, PhD

\begin{abstract}
${ }^{1}$ Discipline of Pharmaceutical Sciences, College of Health Sciences, Westville Campus, University of KwaZulu-Natal, Durban, South Africa
${ }^{2}$ Discipline of Psychology, School of Applied Human Sciences, University of KwaZulu-Natal, Durban, South Africa

${ }^{3}$ Developing Research, Innovation, Localisation and Leadership (DRILL) programme, College of Health Sciences, University of KwaZulu-Natal, Durban, South Africa

${ }^{4}$ Discipline of Nursing, School of Nursing and Public Health, University of KwaZulu-Natal, Durban, South Africa
\end{abstract}

Corresponding author: F Suleman (sulemanf@ukzn.ac.za)

Early-career academics, apart from formal training in the conduct of research at undergraduate and graduate levels, develop individual research capacity principally 'on the job. ${ }^{[1-3]}$ Research leadership capacity entails research leadership skills development, supervision and mentorship, multidisciplinary team collaborations, grant-writing skills, research career pathing, publication in high-impact journals and dissemination of important research projects and outcomes to policymakers and other stakeholders.

\section{Developing Research Innovation, Localisation and Leadership (DRILL) programme}

The DRILL programme at the University of KwaZulu-Natal (UKZN), Durban, South Africa, nurtures a selected talented group of early-career researchers (DRILL fellows) and is a move towards active, focused development of research leadership capacity and research. In this regard, the shift has been from a more unstructured (laissez-faire) to an increasingly structured and managed (contractual and directed) mode of research supervision and mentorship. The key objectives are:

- to capacitate, train and produce, after 5 years, at least 20 research leaders in health, including early-career academics at UKZN and selected personnel from the KZN Department of Health (DoH)

- to build the eligibility and increase the likelihood of retention of these trained scientists at UKZN and the KZN DoH as a pool of highly skilled researchers on an accelerated research leadership trajectory

- to develop skills of mentorship and supervision in these DRILL fellows to identify, inspire, train and support emerging research talent and build thematic communities of practice.

\section{Outcomes}

The DRILL programme is currently active. An empirical evaluation will be conducted and published at the end of the grant period. Two multidisciplinary cohorts of 10 fellows were enrolled in the programme in October 2016 and 2017, respectively. The high visibility and perceived impact of the programme resulted in a surplus of interested and appropriate candidates. We managed to enrol an unplanned third cohort (5 fellows) in 2019, which was made possible owing to unexpected exchange rate improvements in our financial resources. More females have been enrolled (Table 1).

Research leadership development of these fellows is provided in the form of technical, scientific and research ethics competence, a dedicated,
Table 1. Demographic profile of DRILL fellows by cohort

\begin{tabular}{|c|c|c|c|c|}
\hline Demographic variable & $\begin{array}{l}\text { Total, } \\
N\end{array}$ & $\begin{array}{l}\text { Cohort 1, } \\
n\end{array}$ & $\begin{array}{l}\text { Cohort 2, } \\
n\end{array}$ & $\begin{array}{l}\text { Cohort 3, } \\
n\end{array}$ \\
\hline \multicolumn{5}{|l|}{ Gender } \\
\hline Male & 7 & 3 & 3 & 1 \\
\hline Female & 18 & 7 & 7 & 4 \\
\hline \multicolumn{5}{|l|}{ Race/ethnic group* } \\
\hline Black & 11 & 5 & 3 & 3 \\
\hline White & 2 & 1 & 1 & 0 \\
\hline Indian & 9 & 2 & 6 & 1 \\
\hline Coloured & 3 & 2 & 0 & 1 \\
\hline \multicolumn{5}{|l|}{ Place of employment } \\
\hline UKZN (academic) & 20 & 10 & 5 & 5 \\
\hline KZN DoH (clinical) & 5 & 0 & 5 & 0 \\
\hline \multicolumn{5}{|l|}{ Stage of research } \\
\hline $\mathrm{PhD}$ & 10 & 1 & 6 & 3 \\
\hline Post-doc & 15 & 9 & 4 & 2 \\
\hline \multicolumn{5}{|l|}{ Age, years } \\
\hline$<40$ & 14 & 4 & 6 & 4 \\
\hline$\geq 40$ & 11 & 6 & 4 & 1 \\
\hline \multicolumn{5}{|l|}{ Scientific track } \\
\hline $\begin{array}{l}\text { Health professions } \\
\text { education }\end{array}$ & 5 & 2 & 2 & 1 \\
\hline $\begin{array}{l}\text { Health systems } \\
\text { strengthening }\end{array}$ & 7 & 3 & 3 & 1 \\
\hline HIV/AIDS & 6 & 3 & 3 & 0 \\
\hline Mental health & 5 & 2 & 1 & 2 \\
\hline Health research ethics & 2 & 0 & 1 & 1 \\
\hline \multicolumn{5}{|l|}{ Discipline } \\
\hline Physiotherapist & 3 & 2 & 1 & 0 \\
\hline Optometrist & 3 & 1 & 2 & 0 \\
\hline Pharmacist & 2 & 1 & 1 & 0 \\
\hline Nurse & 3 & 1 & 2 & 0 \\
\hline Medical specialist & 4 & 1 & 3 & 0 \\
\hline Physiologist & 2 & 2 & 0 & 0 \\
\hline Neuroscientist & 2 & 2 & 0 & 0 \\
\hline Anatomist & 2 & 0 & 1 & 1 \\
\hline Psychologist & 2 & 0 & 0 & 2 \\
\hline Audiologist & 1 & 0 & 0 & 1 \\
\hline Sports scientist & 1 & 0 & 0 & 1 \\
\hline
\end{tabular}




\section{Short Communication}

well-resourced and supportive environment, and systematic supervision and mentoring from established locally based research leaders. DRILL fellows are required to maintain a research portfolio comprising 6 components: an individual development plan (to document activities for reporting back to our funder); a reflective journal (to allow for deliberation on their career path, goals and reflective practice); research competencies (skills and competencies acquired); health communication and social media engagement (communicating research to the lay media); a teaching portfolio; and preparation for formal rating by our national research council. Writing and communication skills are also integral, especially the production of articles in high-impact publications.

\section{Conclusions}

Although empirical data are currently being collected for future analysis and publication, we believe that DRILL is a unique, comprehensive research leadership programme that will help our institution and the region to maintain its national and international standing as a leader in high-impact evidence-based solutions to pressing regional health problems.

\section{Declaration. None.}

Acknowledgements. The authors acknowledge support from Prof. J Burns, initial principal investigator of DRILL, Prof. M Moshabela and Dr S Ramlall, members of the DRILL leadership team and the KZN DoH.
Author contributions. All authors contributed to: (i) conception and design of the programme; (ii) drafting or critical revision of the article for intellectual content; and (iii) approval of the version to be published.

Funding. The DRILL project is supported by the Fogarty International Center (FIC), National Institutes of Health (NIH) Common Fund, Office of Strategic Coordination, Office of the Director (OD/OSC/CF/NIH), Office of AIDS Research, Office of the Director (OAR/NIH), National Institute of Mental Health (NIMH/NIH) of the National Institutes of Health under award number D43TW010131 (under the scientific areas of HIV/AIDS, mental health, health professions education, health research ethics and health systems research). The content is solely the responsibility of the authors and does not necessarily represent the official views of the NIH.

Conflicts of interest. None.

1. Lalloo U, Bobat RA, Pillay S, et al. A strategy for developing future academic leaders for South Africa in a resource-constrained environment. Acad Med 2014;89(8). https://doi.org/10.1097/ACM0000000000000354

2. Uthman GA, Wiysonge CS, Ota MO, et al. Increasing the value of health research in the WHO African Region beyond 2015 - reflecting on the past, celebrating the present and building the future: A bibliometric analysis. BMJ Open 2015;5:e066340. https://doi.org/10.1136/bmjopen-2014-006340

3. Chu KM, Jayaraman S, Kyamanywa P, et al. Building research capacity in Africa: Equity and global health collaborations. PLoS Med 2014;11(3):e1001612. https://doi.org/10.1371/journal.pmed.1001612

Accepted 27 July 2020.

Afr J Health Professions Educ 2021;13(1):10-11. https://doi.org/10.7196/AJHPE.2021. v13i1.1422 